\title{
Spatial Distribution of Land Cover and Vegetation Activity along Topographic Gradient in an Arid River Valley, SW China
}

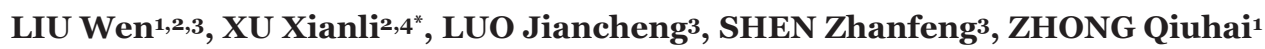 \\ 1 Department of Automatic Control, School of Automation, Beijing Institute of Technology, Beijing 10oo81, China \\ 2 State Key Laboratory of Urban and Regional Ecology, Research Center for Eco-Environmental Sciences, Chinese Academy \\ of Sciences, Beijing 100085, China \\ 3 Institute of Remote Sensing Applications, Chinese Academy of Sciences, Beijing 100101, China \\ 4 Centre for Hydrology, Micrometeorology and Climate Change, Department of Civil and Environmental Engineering, \\ University College Cork, Cork, Ireland \\ *Corresponding author, E-mail: xuxianliww@gmail.com
}

\begin{abstract}
Anthropogenic activities have become more and more important in characterizing the landscape, but their impacts are still restricted by natural environments. This paper discusses the interactions of anthropogenic activity, vegetation activity and topography through describing the spatial distribution of land cover and vegetation activity (represented by Normalized Difference Vegetation Index, NDVI) along topographic gradient in a mountainous area of southwestern China. Our results indicate that the existing landscape pattern is controlled by anthropogenic activities as well as topographic factors. Intensive anthropogenic activities mainly occur in areas with relatively low elevation, gentle and concave slopes, as these areas are easy and convenient to attain for human. Because of the destruction by human, some land cover types (mainly grassland and shrub) are only found in relatively harsher environments. This study also finds that topographic wetness index $(W)$ used in other places only reflects runoff generation capacity, but not indicate the real spatial pattern of soil water content in this area. The relationships between NDVI and $W$, and NDVI and length slope factor $(L S F)$ show that runoff and erosion have complex effects on vegetation activity. Greater values of $W$ and $L S F$ will lead to stronger capacity to produce runoff and transport sediment, and thereby increase soil water content and
\end{abstract}

Received: 11 December 2008

Accepted: 26 February 2009 soil deposition, whereas beyond a certain threshold runoff and erosion are so strong that they would destruct vegetation growth. This study provides information needed to successfully restore native vegetation, improve land management, and promote sustainable development in mountainous areas, especially for developing regions.

Keywords: Vertical distribution of land cover; Anthropogenic activity; Vegetation activity; Environmental variability; China

\section{Introduction}

Vitousek (1994) identified land cover change as the most pervasive human impact on natural systems. Many studies have pointed out the great impact of anthropogenic activity on land cover change and its ecological consequences (Chen et al. 2001; Liu et al. 2003; Jordan et al. 2005; Fu et al. 2005). Unsuitable land uses could cause land degradation, and further cause soil and water losses. It would not only reduce land productivity, but also degrade ecosystems and deteriorate environments (Fu et al. 2000, 2004). However, the impact intensity of anthropogenic activity is still restricted to a certain extent by environmental factors, especially in mountainous areas (Pinder $\amalg$ 
et al. 1997). Environmental variability, particularly topographic features (e.g., elevation, slope steepness and slope aspect) and their influences on soil water distribution (Canton et al. 2004) greatly impact the spatial patterns of land cover. Limited water resources in arid environments make vegetation restoration challenging ( $\mathrm{Ma}$ et al. 2004). Knowing the growth status of the existing vegetation and its spatial pattern along topographic gradient is important for vegetation restoration practices. As all described above, there exist some feedback relationships among anthropogenic activity, vegetation and environment. It is interesting as well as important to know the interaction mechanisms (Linderman et al. 2006), which can help restore vegetation, improve land management and promote sustainable development in mountainous areas.

The arid river valley of the upper reaches of the Minjiang River, SW China, is a typical area representing the interactions mentioned above (Xu et al. 2008a, 2008b). It is a key region for ecoenvironmental reconstruction under the National Eco-environmental Renovating Scheme of China (Li et al. 2006). Therefore, it is both necessary and significant to study the interactions among the anthropogenic activity, vegetation growth and environmental variability (especially topographic features) in this area.

According to the prior analysis, this study focused on two objectives: (1) describing the interactions between the anthropogenic activities and topographic factors, and their controlled landscape patterns; (2) seeking the relationships of vegetation activity with topographic features and topography-controlled soil-water distribution.

\section{Methods}

\subsection{Study area}

The Minjiang River is a first-order branch of the Yangtze River (Figure 1). The river is not only important economically, but also ecologically in southwestern China. It is the main water resource of the Sichuan Province, determining the production of agriculture and industry in the region. The watershed is inhabited by many rare species, such as the giant panda. Located on the transitional zone from the Tibetan Plateau to the Sichuan Basin, the Upper Minjiang River basin $\left(102^{\circ} 41^{\prime} \sim 103^{\circ} 58^{\prime} \mathrm{E} ; 30^{\circ} 44^{\prime} \sim 32^{\circ} 24^{\prime} \mathrm{N}\right)$ refers to the section upward from Dujiangyan City, and is about 337 kilometers long. The topography of the area is characterized by the complex distribution of mountains and valleys ranging in elevation from 700 to $6260 \mathrm{~m}$ with average elevation difference above $1000 \mathrm{~m}$. Its temperature is obviously related to latitude and altitude with a vertical declining rate about $0.46{ }^{\circ} \mathrm{C} / 100 \mathrm{~m}$. In the north the elevation is more than $2000 \mathrm{~m}$ it is extremely cold and annual precipitation is $730 \sim 840 \mathrm{~mm}$, and in the south arid river valleys occur with an elevation of $1200 \sim 2000 \mathrm{~m}$ and annual precipitation of $420 \sim 566 \mathrm{~mm}$. More than $80 \sim 90 \%$ of the annual precipitation falls from May to October. The brown forest soil in the region is rich in lime (Bureau of Agriculture and Pasturage, Office of Soil Survey, Sichuan Province 1997). Regional vegetation mainly consists of small-leaf arid shrubs (elev. 1300 2200 m), evergreen and deciduous broadleaved mixed forests and broad-leaved and coniferous mixed forests (elev. 2000 2800 m), coniferous forests (Picea and Abies) (elev. 2800 3600 $\mathrm{m}$ ), and alpine shrubs and meadows (elev. $>3600 \mathrm{~m}$ ) (Zhang 1992). The whole population in this region in 2000 reached 385,300 and people mainly inhabit in river-valley areas. Detailed information on those areas can be referenced to Ma et al. (2004) and Li et al. (2006). We selected the section of arid river valley (elev. $1300 \sim 2900 \mathrm{~m}$ ) from Shidaguan to Wenchuan in a length about $90 \mathrm{~km}$ for this study (Figure 1).

\subsection{Data and processing}

Land cover map (1997) was acquired from the Data Center for Resources and Environmental Sciences, Chinese Academy of Sciences (RESDC).1) Among the original land cover types, paddy field and dry land were combined into farmland, and sparse forest was integrated into shrub. The finally classified types used in this study are listed and described in Table 1.

The use of remote sensing to analyze

1) http://www.resdc.cn/resdc/b-f/fen-1.asp\#8 (Accessed 26th May, 2009) 


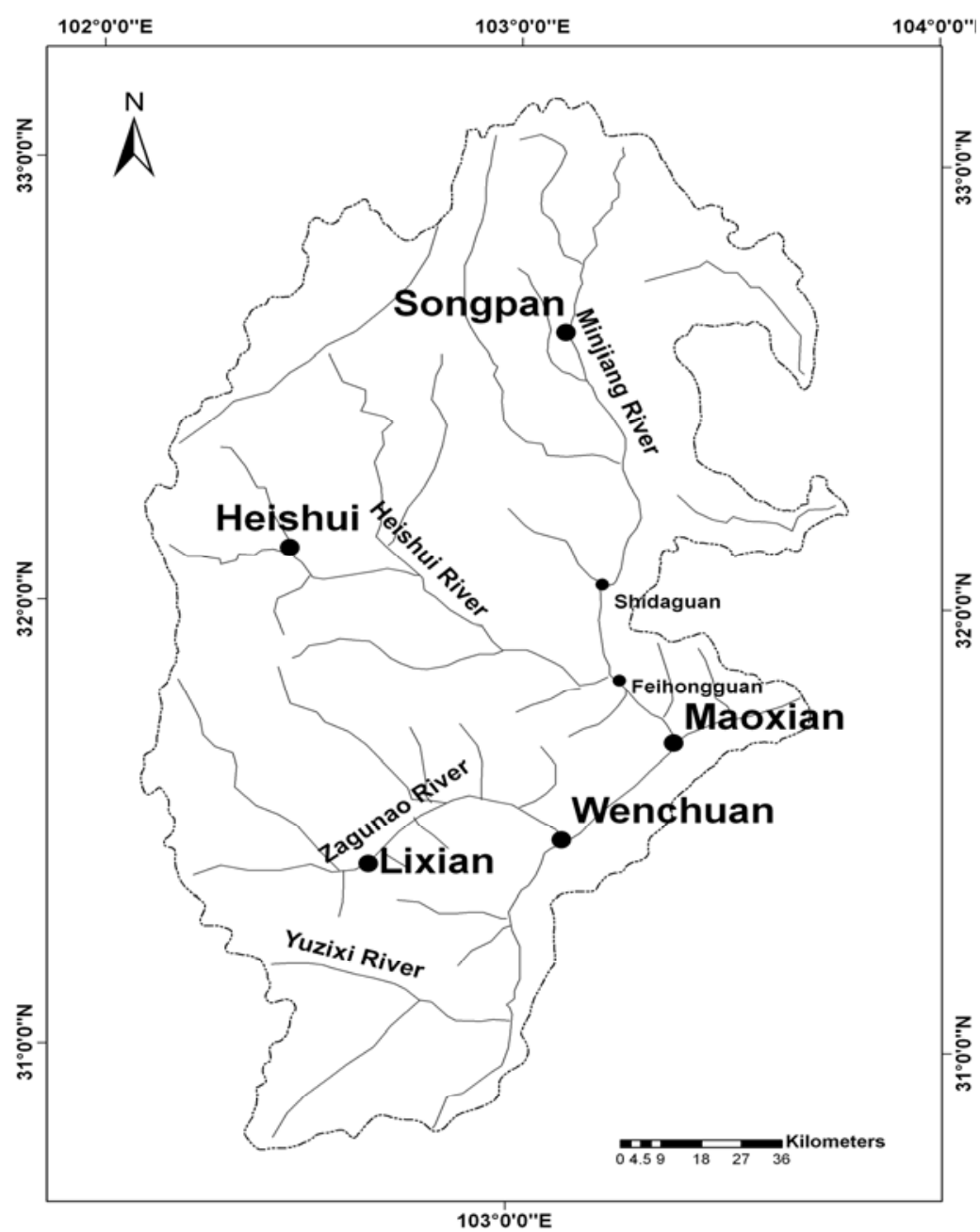

Figure 1 The study area (from Shidaguan, via Feihongguan to Wenchuan)

Table 1 The classified land covers and its descriptions

\begin{tabular}{|l|l|l|l|}
\hline $\begin{array}{l}\text { Land cover } \\
\text { classification }\end{array}$ & Code & $\begin{array}{l}\text { Area } \\
\left(\mathrm{km}^{2}\right)\end{array}$ & Descriptions \\
\hline Farmland & 1 & 55.2 & Lands covered with temporary crops followed by harvest and a bare soil period. \\
\hline Forest & 2 & 19.6 & Lands dominated by tree communities. \\
\hline Shrub & 3 & 163.1 & Lands with woody vegetation less than 2 m. \\
\hline Nursery garden & 4 & 26.7 & Lands with seedlings \\
\hline Grassland & 5 & 289.8 & Lands with herbaceous plants \\
\hline Town and village & 6 & 2.2 & Lands covered by buildings and other man-made structures. \\
\hline Barren and snow & 7 & 9.5 & Lands with exposed rocks, and lands under ice and/or snow. \\
\hline Water bodies & 8 & 16.4 & Lakes, reservoirs and rivers. \\
\hline Total & - & 582.6 & - \\
\hline
\end{tabular}

vegetation activity was based on the spectral properties of vegetation, which absorbed an important percentage of electromagnetic energy in the visible region and reflected a high percentage in the near-infrared region. Due to these properties, different vegetation indices based on combinations of red and infrared bands could be calculated. We selected Landsat ETM+ satellite image (acquired 
on 10 July 2002, from the GLCF, Institute of Geographic Sciences and Natural Resources Research, Chinese Academy of Sciences) to calculate the Normalized Difference Vegetation Index (NDVI), based on the formula, $N D V I=(N I R$ Red)/(NIR+Red) (Similar to Morawitz et al. 2006).

The digitized topographic map (1:50,000) was rasterized with $30 \mathrm{~m}$ resolution, upon which all topographic indices were derived. They are as follows:

(a) Slope angle ( $S L O)$

(b) Slope aspect

(c) Slope profile curvature. Related to flow acceleration, it is an important determinant of erosion and deposition processes at the hill slope scale (Moore et al. 1991).

(d) Topographic wetness index $(w)$, with $w=\ln$ (Contributing area/ tan SLO) (Beven and Kirkby 1979), is related to the spatial distribution and size of zones of saturation or variable source areas for runoff generation. Contributing area is calculated as the number of upstream cells draining to a target cell, using a single drainagedirection algorithm.

(e) Length slope factor $(L S F)$ is a potential sediment transport index, namely LS factor in USLE (Universal Soil Loss Equation) (Wischmeier and Smith 1978):

$L=(\text { Contributing area } \times 30 / 22.13)^{m}$,

$S L O<0.57^{\circ}, \quad m=0.2 ; \quad S L O>=0.57^{\circ} \quad$ and $S L O<1.72^{\circ}, m=0.3 ; S L O>=1.72^{\circ}$ and $S L O<2.86^{\circ}$, $m=0.4 ; S L O>=2.86^{\circ}, m=0.5$.

For slope factor (Liu et al. 1994), if $S L O<5^{\circ}, S=$ $10.8 \sin S L O+0.03 ; S L O>=5^{\circ}$ and $S L O<10^{\circ}$, $S=16.8 \sin S L O-0.5 ; S L O>=10^{\circ}, S=21.91 \sin S L O-$
0.96 .

To facilitate data analysis, we classified each topographic variable into some intervals (Table 2) to represent topographic gradient. To seek land cover changing trends along topographic gradient, we calculated abundance for each land cover in each interval, namely, the ratio of area covered by certain land cover type to the total area of the interval. Likewise, we calculated the averaged NDVI for each interval of topographic gradient to explore the changes in vegetation activities along topographic gradient.

\subsection{Statistical method}

To detect the changing trends of some variables (dependent variables) along topographic gradient (independent variables), we directly fitted the dependent variables with topographic classes' code. Therefore, the fitted curves could only reflect the changing trends, but not the specific magnitude of the change. All the statistical analyses were conducted with the Spss Software (10.0.1).

\section{Results}

\subsection{Elevation and topography}

The major areas sampled occur at an elevation range from 1300 to $2900 \mathrm{~m}$, and the relative elevation to the Minjiang River falls into the range from -103 (areas below the Minjiang River) to 1000 m. Slopes of $>25^{\circ}$ account for more than $70 \%$ of each relative elevation interval except the intervals of $<100 \mathrm{~m}(38 \%)$ and 900 1000 $\mathrm{m} \mathrm{(67 \% ).}$

Table 2 Topographic gradient intervals and their codes

\begin{tabular}{|c|c|c|c|c|c|c|c|c|c|c|}
\hline $\begin{array}{l}\text { Code } \\
\text { Factors }\end{array}$ & 1 & 2 & 3 & 4 & 5 & 6 & 7 & 8 & 9 & 10 \\
\hline $\begin{array}{l}\text { Relative } \\
\text { elevation (m) }\end{array}$ & $<100$ & $100 \sim 200$ & $200 \sim 300$ & $300 \sim 400$ & $400 \sim 500$ & $\begin{array}{l}500 \sim \\
600\end{array}$ & $\begin{array}{l}600 \sim \\
700\end{array}$ & $\begin{array}{l}700 \sim \\
800\end{array}$ & $\begin{array}{l}800 \sim \\
900\end{array}$ & $\begin{array}{l}900 \sim \\
1000\end{array}$ \\
\hline Slope angle $\left(^{\circ}\right)$ & $<3$ & $3 \sim 7$ & $7 \sim 15$ & $15 \sim 25$ & $>25$ & & & & & \\
\hline $\begin{array}{l}\text { Slope } \\
\text { aspect }\left({ }^{\circ}\right)\end{array}$ & $\begin{array}{l}0 \sim 22.5 \\
\text { and } \\
337.5 \sim \\
360\end{array}$ & $\begin{array}{l}22.5^{\sim} \\
67.5 \text { and } \\
292.5^{\sim} \\
337.5\end{array}$ & $\begin{array}{l}67.5^{\sim} \\
112.5 \text { and } \\
247.5^{\sim} \\
292.5\end{array}$ & $\begin{array}{l}112.5^{\sim} \\
157.5^{2} \text { and } \\
202.5^{\sim} \\
247.5^{2}\end{array}$ & $\begin{array}{l}157.5 \sim \\
202.5\end{array}$ & & & & & \\
\hline $\begin{array}{l}\text { Profile } \\
\text { curvature }\end{array}$ & Convex & Straight & Concave & & & & & & & \\
\hline $\begin{array}{l}\text { Length slope } \\
\text { factor }\end{array}$ & $0 \sim 5$ & $5 \sim 10$ & $10 \sim 15$ & $15 \sim 20$ & $20 \sim 30$ & $>30$ & & & & \\
\hline $\begin{array}{l}\text { Topographic } \\
\text { wetness index }\end{array}$ & $\begin{array}{l}0.28 \sim \\
0.4\end{array}$ & $\begin{array}{l}0.40 \sim \\
0.55\end{array}$ & $\begin{array}{l}0.55^{\sim} \\
0.70^{-}\end{array}$ & $\begin{array}{l}0.70 \sim \\
0.85\end{array}$ & $0.85 \sim 1$ & & & & & \\
\hline
\end{tabular}


Table 3 Changing trends of topographic characteristics and land cover abundance along elevation

\begin{tabular}{|c|c|c|c|c|c|c|c|c|c|}
\hline Dependent variables & $\begin{array}{l}\text { Math } \\
\text { function }\end{array}$ & $\mathrm{R}^{2}$ & $\begin{array}{l}\text { Degree of } \\
\text { freedom }\end{array}$ & $\mathrm{F}$ & $p$ & $b_{o}$ & $b_{1}$ & $\mathrm{~b}_{2}$ & $b_{3}$ \\
\hline \multicolumn{10}{|l|}{ Topogrphic factors } \\
\hline Slope angle & LIN & 0.261 & 8 & 2.82 & 0.132 & 28.05 & 0.7 & & \\
\hline Convex slope & LIN & 0.621 & 8 & 13.12 & 0.007 & 33.37 & 2.02 & & \\
\hline Concave slope & LIN & 0.599 & 8 & 11.93 & 0.009 & 53.89 & -1.4 & & \\
\hline Length slope factor & LIN & 0.061 & 8 & 0.52 & 0.49 & 19.37 & 0.25 & & \\
\hline Topographic wetness index & LIN & 0.673 & 8 & 16.5 & 0.004 & 0.79 & -0.01 & & \\
\hline \multicolumn{10}{|l|}{ Land cover } \\
\hline Farmaland & CUB & 0.883 & 6 & 15.11 & 0.003 & 6.33 & 7.86 & -1.78 & 0.10 \\
\hline Forest & LIN & 0.981 & 8 & 411.58 & 0.000 & -1.41 & 0.84 & & \\
\hline Shrub & LIN & 0.98 & 8 & 395.46 & 0.000 & 2.63 & $4 \cdot 45$ & & \\
\hline Nursery garden & EXP & 0.965 & 8 & 217.42 & 0.000 & 49.09 & -0.68 & & \\
\hline
\end{tabular}

$L I N: y=b_{0}+b_{1} x ; E X P: y=b_{0} e^{b_{1} x} ; C U B: y=b_{0}+b_{1} x+b_{2} x^{2}+b_{3} x^{3}$

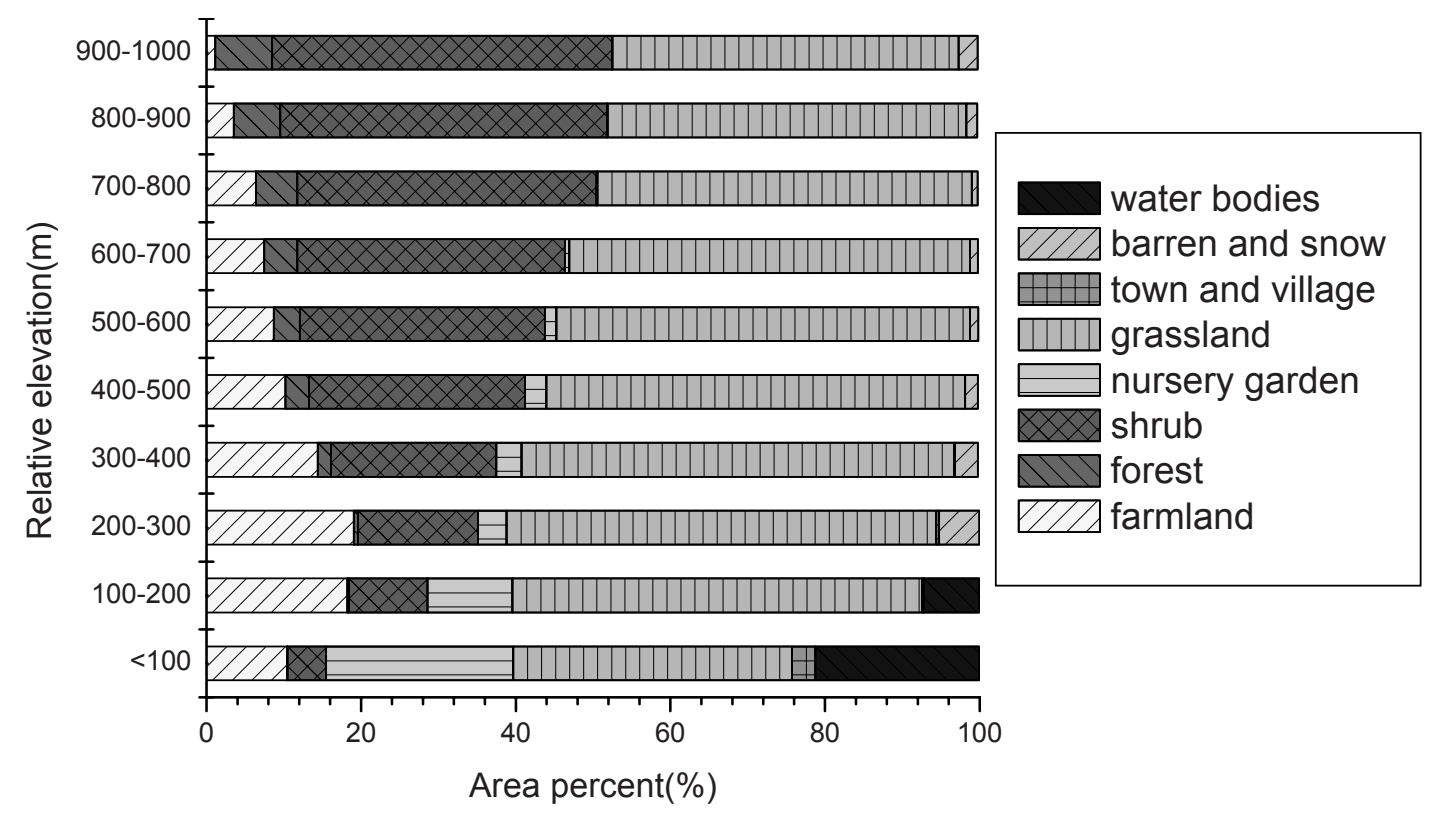

Figure 2 Land cover distribution along altitude gradient

Slope steepness increases (positive $b_{1}$, Table 3), but not significantly ( $p>0.05$ ) with elevation increasing. Since the Minjiang River valley running from north to south, the slope aspects of the valley are mainly east and west facing. Abundance of convex slope significantly increases with elevation increasing ( $p<0.05$, Table 3 ), while the trend for that of concave slope is opposite $(p<0.05)$.

The interval of 20 30 of LSF account for $30 \%$ of this area, and followed by the intervals of $>30$
(19.7\%), 15 20(17.7\%) and 10 15(17.1\%). There exists an increasing but not significant trend with elevation for LSF (positive $b_{1}$ but $p>0.05$, Table 3 ). Most of this area has intermediate values of topographic wetness index $0.55^{\sim 0.70 ~(32.7 \%) . ~}$ Mesic values of $0.85 \sim 1$ are more common within $100 \mathrm{~m}$, vertical distance to valley bottom. The values of topographic wetness index decrease as vertical distance to valley bottom increases (negative $\mathrm{b}_{1}$ and $p<0.05$, Table 3 ). 


\subsection{Relationship between abundance of land cover and elevation}

Shrub and grassland are the dominant land cover types, accounting for $28.0 \%$ and $49.8 \%$ of the total area $\left(583 \mathrm{~km}^{2}\right)$, respectively. Farmland accounts for $9.5 \%$, and towns and villages only cover the least area, about $0.4 \%$ of the total area.

As elevation increasing, abundance of farmland firstly increases and then decreases (Figure 2; $p<0.05$, Table 3 ). The farmland is mainly concentrated within $500 \mathrm{~m}$ to valley bottom, and the greatest abundance is in the interval of 200 300 m. Abundance of forest and shrub increases with elevation ( $p<0.05$, Table 3$)$. The nursery garden is mainly concentrated within 100 $\mathrm{m}$, and abruptly decreases with increasing of elevation $(p<0.05$, Table 3$)$. Grassland is always dominant in each relative elevation interval, and especially in the intermediate relative elevation range (200 700 m). Towns and villages mainly occur in the $<100 \mathrm{~m}$ interval, namely, at valley bottom. Water bodies, especially the Minjiang River, are also at the valley bottom. The land cover types of barren and snow are found in low relative elevation intervals (barren, 200 500 $\mathrm{m}$ ) and high relative elevation intervals (snow, 800 1000 m), respectively.

As shown in Figure 3, the mean relative elevation values are in a descending order: forest (723.5 $\mathrm{m})$, shrub $(649.4 \mathrm{~m})$, barren and snow $(529.5 \mathrm{~m}$,$) , grassland (516.8 \mathrm{~m})$, farmland (378.9 $\mathrm{m})$, nursery garden $(146.4 \mathrm{~m})$, town and village

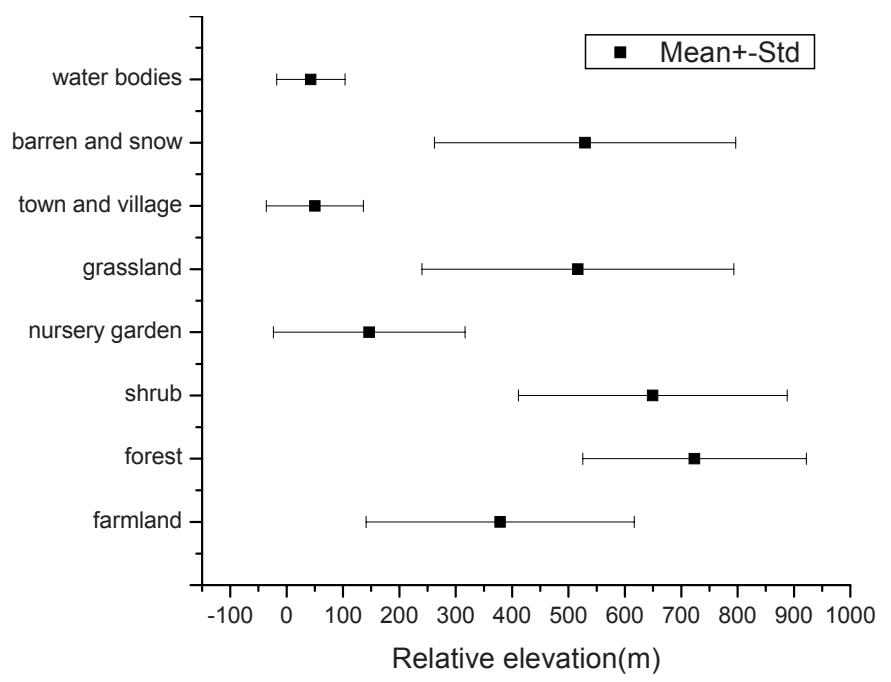

Figure 3 The mean relative elevation (relative to the Minjiang River) for each land cover type
(50.2 $\mathrm{m})$ and water bodies $(43 \mathrm{~m})$. In fact, three groups are presented in Figure 3. The first one in low relative elevation ranges includes nursery garden, town and village, and water bodies; the second in intermediate ranges includes farmland; and the third in high ranges includes forest, shrub, grassland, and barren and snow.

All described above present the vertical landscape pattern in this area.

\subsection{Relationship between abundance of land cover types and topographic position}

Abundance of farmland firstly increases and then decreases over slope steepness (Figure 4a), and the changing trend can be fitted by Cubic model (Table 4, $\mathrm{R}^{2}=0.995$ and $p=0.086$ ). They cover $<10 \%$ of every slope steepness interval except $7 \sim 15^{\circ}$ (14.0\%) and $15 \sim 25^{\circ}$ (14.6\%) intervals. Because above $70 \%$ of this area is $>25^{\circ}$, most part $(59 \%)$ of the farmland still covers steep slope $\left(>25^{\circ}\right)$ irrespective of the policy to return farmland to forest or grassland issued by government. Abundances of forest, shrub, grassland, and barren and snow have the similar distribution pattern over slope steepness, showing the directly increasing trend (positive $\mathrm{b}_{1}$ and $p<0.05$ in Table 4). On steep slopes, shrub and grassland cover the most area. Abundances of nursery garden, towns and villages, and water bodies always decrease over slope steepness (negative $\mathrm{b}_{1}$ and $p<0.05$ in Table 4 ). The slope aspects are classed from 1 to 6 , namely, from north to south, representing the change in solar insolation. As shown in Figure 4b, with the slope aspects from north to south, the abundance of farmland and grassland always increases (positive $\mathrm{b}_{1}$ and $p<0.05$ in Table 4 ), while a contrary trend is found for forest, shrub and nursery garden (negative $b_{1}$ and $p<0.05$ in Table 4). At each interval of slope aspects, grassland and shrub always cover the most area.

For farmland, nursery garden, and town and village, there is a greater abundance at concave than convex slope, while a contrary pattern occurs for forest, shrub and grassland (Figure 4c). In fact, it can demonstrate that the intensive anthropogenic activities (farmland, nursery garden, and town and village) occur much more on concave slopes. 

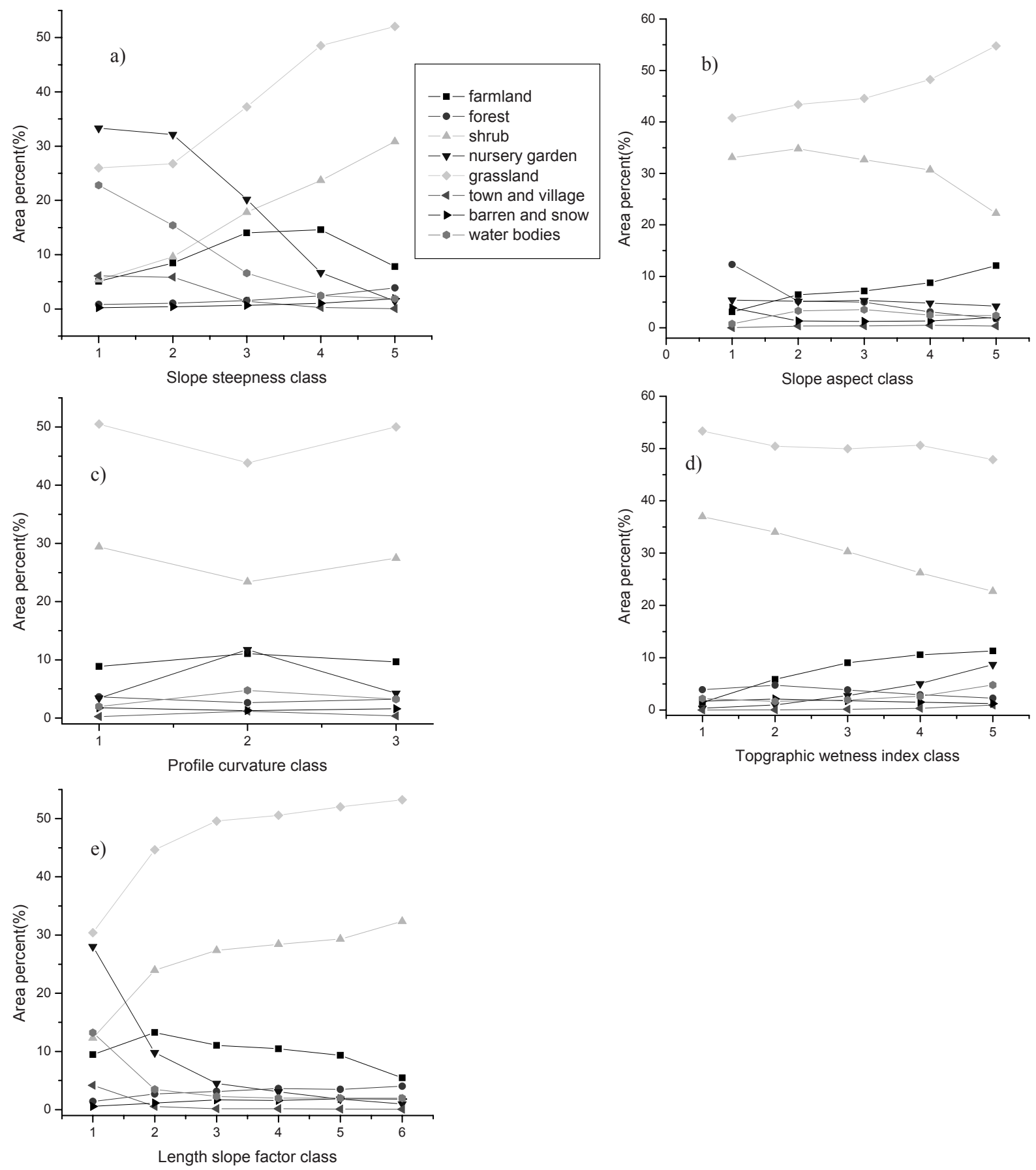

Figure 4 Change in abundance of land cover along topographic gradient: a) Slope steepness, b) Slope aspect, c) Profile curvature, d) Topographic wetness index, e) Length slope factor

\subsection{Relationships between abundance of land cover and $W$ and LSF}

The abundance of farmland, nursery garden, town and village (positive $b_{1}$ and $p<0.05$ ), and water bodies (shown as the right limb of quadratic curve, $\mathrm{b}_{2}>0$ and $p<0.05$ in Table 4 ), increases with increasing topographic wetness index (Figure 4d), that is, they are distributed much more in areas where more runon easily occurs. Most of other land cover types decreased with increasing topographic wetness index (negative $\mathrm{b}_{1}$ and $p<0.05$ ). The 
abundance of forest, shrub and grassland always increases over length slope factor (positive $b_{1}$ and $p<0.05$ ), while that of farmland, nursery garden, town and village, and water bodies is more in the first 3 intervals (Figure 4e). The greater the length slope factor, the stronger the capacity to transport water and sediment is. Generally, human subjectively select the less erodible area to conduct activities, which may also result in other land cover types being restricted to relatively more erodible area.

\subsection{The changes of NDVI along topographic gradient}

NDVI increases over relative elevation classes (shown as the left limb of quadratic curve with poisitive $b_{2}$, see Table 5 and Figure $5 \mathrm{a}$ ), which are

Table 4 Changing trends of land cover abundance (dependent variables) along topographic gradient (independent variables)

\begin{tabular}{|c|c|c|c|c|c|c|c|c|c|}
\hline Variables & $\begin{array}{l}\text { Math } \\
\text { function }\end{array}$ & $\mathrm{R}^{2}$ & $\begin{array}{l}\text { Degree of } \\
\text { freedom }\end{array}$ & $\mathrm{F}$ & $p$ & $\mathrm{~b}_{0}$ & $b_{1}$ & $\mathrm{~b}_{2}$ & $\mathrm{~b}_{3}$ \\
\hline \multicolumn{10}{|l|}{ Slope angle } \\
\hline Farmland & CUB & 0.995 & 1 & 73.27 & 0.086 & 7.17 & -6.67 & $5 \cdot 32$ & -0.79 \\
\hline Forest & EXP & 0.989 & 3 & 271.58 & 0.000 & 0.51 & 0.39 & & \\
\hline Shrub & LIN & 0.993 & 3 & 427.41 & 0.000 & -2.03 & 6.50 & & \\
\hline Nursery garden & LIN & 0.949 & 3 & $55 \cdot 45$ & 0.005 & $45 \cdot 51$ & -8.92 & & \\
\hline Grassland & LIN & 0.943 & 3 & 49.3 & 0.006 & 15.95 & $7 \cdot 39$ & & \\
\hline Town and village & EXP & 0.943 & 3 & 49.85 & 0.006 & 36.54 & -1.21 & & \\
\hline Barren and snow & EXP & 0.999 & 3 & 2589.6 & 0.000 & 0.14 & 0.52 & & \\
\hline Water bodies & LOG & 0.973 & 3 & 109.33 & 0.002 & 23.29 & -14.06 & & \\
\hline \multicolumn{10}{|l|}{ Slope aspect } \\
\hline Farmland & EXP & 0.97 & 3 & 97.53 & 0.002 & 5.02 & 0.20 & & \\
\hline Forest & EXP & 0.892 & 3 & 24.67 & 0.016 & 7.64 & -0.31 & & \\
\hline Shrub & LIN & 0.925 & 3 & 36.91 & 0.009 & 41.58 & -4.75 & & \\
\hline Nursery garden & LIN & 0.801 & 3 & 12.06 & 0.04 & 6.22 & -0.59 & & \\
\hline Grassland & EXP & 0.961 & 3 & 73.88 & 0.003 & 38.59 & 0.08 & & \\
\hline Barren and snow & QUA & 0.988 & 2 & 85 & 0.012 & 1.73 & -0.57 & 0.15 & \\
\hline \multicolumn{10}{|c|}{ Topographic wetness index } \\
\hline Farmland & EXP & 0.738 & 3 & 8.46 & 0.062 & 5.46 & -0.16 & & \\
\hline Forest & LIN & 0.998 & 3 & 1280.8 & 0.000 & 40.94 & -3.64 & & \\
\hline Shrub & POW & 0.984 & 3 & 182.93 & 0.001 & 0.32 & 1.99 & & \\
\hline Nursery garden & LOG & 0.802 & 3 & 12.15 & 0.04 & 53.07 & -2.75 & & \\
\hline Town and village & LIN & 0.796 & 3 & 11.7 & 0.042 & -0.35 & 0.21 & & \\
\hline Water bodies & QUA & 0.988 & 2 & 79.9 & 0.012 & 3.70 & -1.87 & 0.41 & \\
\hline \multicolumn{10}{|c|}{ Length slope factor } \\
\hline Farmland & QUA & 0.868 & 3 & 9.87 & 0.048 & 7.42 & $3 \cdot 32$ & -0.61 & \\
\hline Forest & LOG & 0.959 & 4 & 92.7 & 0.001 & 1.57 & 1.36 & & \\
\hline Shrub & LOG & 0.936 & 4 & 58.26 & 0.002 & $14 \cdot 31$ & 10.32 & & \\
\hline Nursery garden & POW & 0.985 & 4 & 264.92 & 0.000 & 31.39 & -1.80 & & \\
\hline Grassland & LOG & 0.919 & 4 & 45.27 & 0.003 & 33.20 & 12.36 & & \\
\hline Town and village & POW & 0.981 & 4 & 209.55 & 0.000 & 3.41 & -2.40 & & \\
\hline Barren and snow & LOG & 0.928 & 4 & 51.69 & 0.002 & 0.63 & 0.74 & & \\
\hline Water bodies & POW & 0.866 & 4 & 25.89 & 0.007 & 9.71 & -1.06 & & \\
\hline
\end{tabular}

$L I N: y=b_{0}+b_{1} x ; E X P: y=b_{0} e^{b_{1} x} ; Q U A: y=b_{0}+b_{1} x+b_{2} x^{2} ; C U B: y=b_{0}+b_{1} x+b_{2} x^{2}+b_{3} x^{3} ; L O G: y=b_{0}+b_{1} \ln (x) ; P O W: y=b_{0}(x)^{b_{1}}$ 

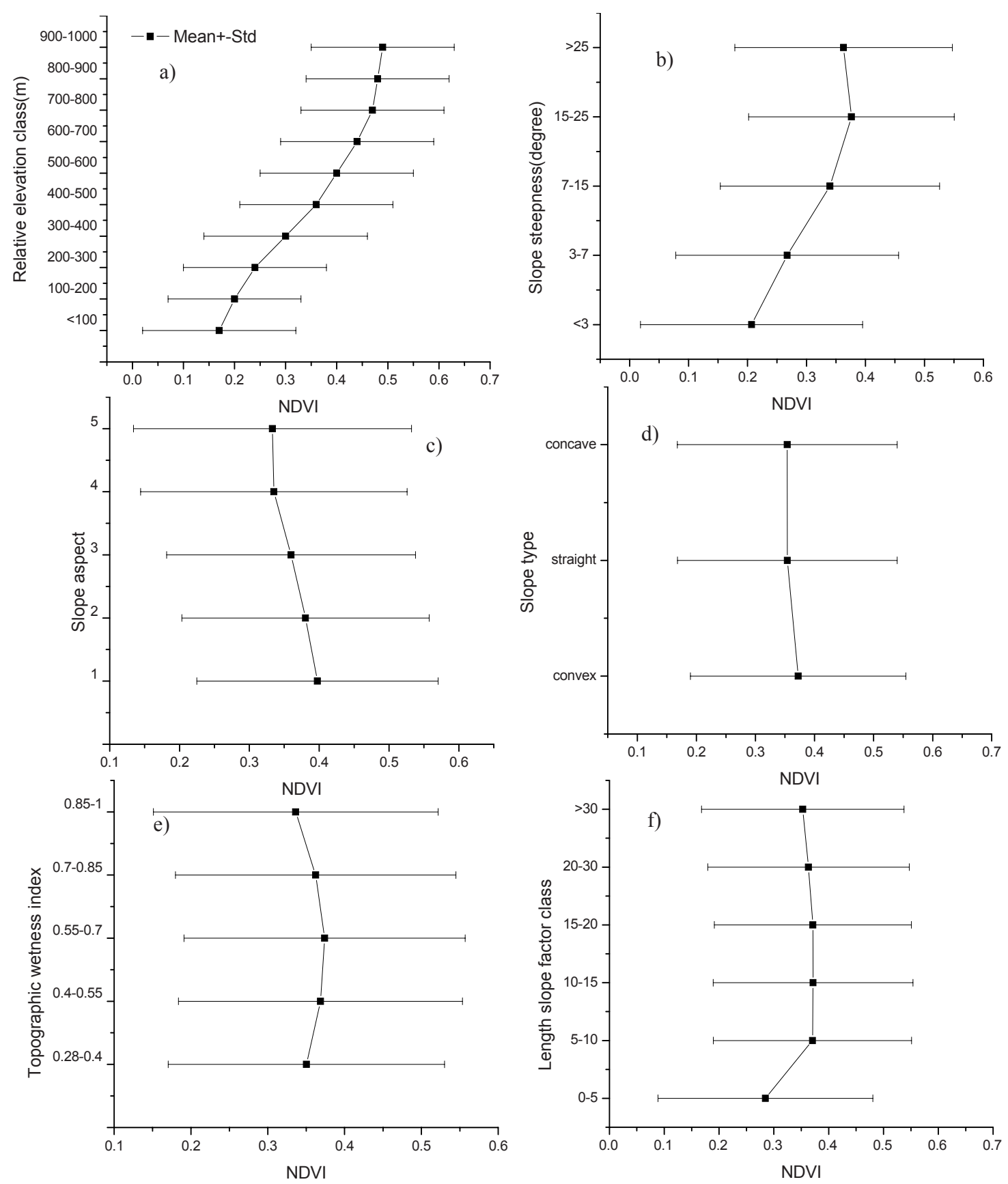

Figure 5 Change in vegetation activity along topographic gradient: a) Relative elevation, b) Slope steepness, c) Slope aspect, d) Profile curvature, e) Topographic wetness index, f) Length slope factor

Table 5 Changing trends of NDVI along topographic gradient

\begin{tabular}{|l|l|l|l|l|l|l|l|l|}
\hline Dependent variables & $\begin{array}{l}\text { Math } \\
\text { function }\end{array}$ & $\mathrm{R}^{2}$ & $\begin{array}{l}\text { Degree of } \\
\text { freedom }\end{array}$ & $\mathrm{F}$ & $p$ & $\mathrm{~b}_{0}$ & $\mathrm{~b}_{1}$ & $\mathrm{~b}_{2}$ \\
\hline Relative elevation & QUA & 0.988 & 7 & 286.16 & 0.000 & 0.086 & 0.07 & -0.003 \\
\hline Slope angle & QUA & 0.980 & 2 & 50.20 & 0.020 & 0.093 & 0.12 & -0.013 \\
\hline Slope aspect & EXP & 0.961 & 3 & 73.10 & 0.003 & 0.416 & -0.05 & \\
\hline Topographic wetness index & QUA & 0.999 & 2 & 971.81 & 0.001 & 0.316 & 0.04 & -0.008 \\
\hline Length slope factor & QUA & 0.806 & 3 & 6.22 & 0.086 & 0.234 & 0.07 & -0.009 \\
\hline
\end{tabular}

EXP: $y=b_{0} e^{b_{1} x} ; Q U A: y=b_{0}+b_{1} x+b_{2} x^{2}$ 
closely related to vegetation distribution, e.g., most part of high elevation is covered by grassland, shrub and forest. NDVI increases along slope gradient till the interval $15^{\circ} \sim 25^{\circ}$ (Figure $5 \mathrm{~b}$ ), and then slightly decreases (The trend could be fitted with quadratic curve, $p<0.05$, Table 5 ). It may be consistent with the pattern of land cover such as grassland, shrub and forest, which cover most part of steep slope. However, these land cover types become much sparser beyond $25^{\circ}$ for the difficulty in standing, and thereby result in decrease in NDVI. Regarding slope aspect (Figure 5c), the highest NDVI is in north facing slope, and the lowest in south facing slope. It is in agreement with the solar insolation and soil moisture conditions in different aspect-facing slopes. NDVI is slightly higher in convex slope than concave one (Figure $5 \mathrm{~d}$ ), as abundance is slightly higher for forest, shrub and grassland in convex slope than in concave ones. As for the topographic wetness index and length slope factor gradient (Figures 5e and 5f), NDVI initially increases and then decreases (The trend could be fitted with quadratic curve, $p<0.05$, Table 5).

\section{Discussion}

\subsection{Anthropogenic activities together with topography controlling landscape pattern}

As shown in the Results section, farmland, nursery garden, and town and village are mainly distributed within $500 \mathrm{~m}$ relative to valley bottom (classes 1 5). These land cover types mainly reflect intensive anthropogenic activities. Nursery garden, and town and village should be distributed near the valley bottom, where is mostly gentle and flat, and thereby favorable for construction operations. Farmland is near the towns and villages, and convenient to be attained for farmers, but distributed in relatively higher elevation because the town and village covers most of the valley bottom. At higher elevations, the slope is relatively more steep and convex, and it is difficult for human to conduct activities. This area is covered mainly by sparse grassland and shrub as it is harsh for the growth of other plants. Overall, along elevation gradient from high to low level, the vertical landscape pattern is formed in turn by forest, shrub, barren and snow, grassland, farmland, nursery garden, town and village, and water bodies (Figures 2 and 3).

Generally, intensive anthropogenic activities mainly occur in the areas with relatively low elevation, gentle and concave slopes, as it is convenient for human to get in these areas. Meanwhile, because of the destruction by human, grassland and shrub are only restricted to relatively harsher environments. It demonstrates that anthropogenic activities have great impacts on the landscape pattern. However, the activities are also restricted by topographic factors such as steep slope and high elevation. In conclusion, the anthropogenic activities together with topographic factors control the existing landscape pattern.

\subsection{Vegetation activity in relation to soil water content, runoff and erosion}

As described in the previous section, NDVI increases over elevation (Figure 5a). NDVI is highly related to net primary production, vegetation cover and leaf area index (Sellers 1985). Some research on vegetation activity in this area could support our results (Liu et al. 2003; Li et al. 2005; Li et al. 2006). Liu et al. (2003) reported the biomass of the shrubs (Onosma farrerii and Aiania potaninii) increased over elevation. $\mathrm{Li}$ et al.(2005) and $\mathrm{Li}$ et al.(2006) documented that leaf area of cotinus coggygria and Sophora davidii increasesd with altitude gradient. Soil moisture, most of which comes from rainfall, is the major limiting factor for vegetation growth in arid environments (Ma et al. 2004). Thus, NDVI has a positive relationship with soil moisture, which can also be demonstrated by the trend of NDVI decreasing over slope aspects from north to south facing (Figure 5c). Moore et al. (1988) found a strong correlation between the distribution of topographic wetness index and the distribution of surface soil water content in a small fallow catchment. However, in our results, topographic wetness index has a decreasing trend over elevation (Table 3), which demonstrates topographic wetness index cannot correctly present the real conditions of soil moisture in this area, and can only reflect runoff redistribution controlled by topographic factors. Therefore, the relationship between NDVI and topographic wetness index only reflects the effects of runoff generation on 
vegetation activity.

Runoff and erosion have complex effects on vegetation activity, that is, NDVI increases first and then decreases over topographic wetness index and length slope factor (Table 5). Greater values of topographic wetness index and length slope factor would lead to stronger capacity to produce runoff and transport sediment to increase soil water content and soil deposition, whereas beyond a certain threshold, runoff and erosion is so strong that they would destruct vegetation growth.

\section{Conclusions}

With the aid of GIS and RS techniques, this study discussed the interactions among anthropogenic activity, vegetation activity and topography through describing the spatial distribution of land cover and vegetation activity along topographic gradient. Intensive anthropogenic activities (as represented by farmland, nursery garden, and town and village) mainly occur in the areas with relatively low elevation, gentle and concave slopes, while grassland and shrub are only distributed in relatively harsher environments. The existing landscape pattern is controlled by anthropogenic

\section{References}

Beven, K. J., Kirkby, M. J. 1979. A physically based, variable contribution area model of basin hydrology. Hydrological Science Bulletin 24: 43-69.

Bureau of Agriculture and Pasturage, Office of Soil Survey, Sichuan Province. 1997. Soil of Sichuan. Chengdu: Science and Technology Press of Sichuan. (In Chinese)

Canton, Y., Del Barrio, G., Sole-Benet, A., et al. 2004. Topographic controls on the spatial distribution of ground cover in the Tabernas badlands of SE Spain. Catena 55: 341365.

CHEN Liding, WANG Jun, FU Bojie, et al. 2001. Land use change in a small catchment of northern Loess Plateau, China. Agriculture, Ecosystems \& Environment 86: 163-172.

FU Bojie, MENG Qinghua, QIU Yang, et al. 2004. Effects of land use on soil erosion and nitrogen loss in the hilly area of the Loess Plateau, China. Land Degradation and Development 15: 87-96.

FU Bojie, CHEN Liding, MA Keming, et al. 2000. The relationships between land use and soil conditions in the hilly area of the loess plateau in northern Shaanxi, China. Catena 39: $69-78$.

FU Bojie, ZHAO Wenwu, CHEN Liding, et al. 2005. Ecohydrological effects of landscape pattern change. Landscape Ecological Engineering 1: 25-32. activities as well as topographic factors. The relationships between NDVI and $W$, and NDVI and length slope factor $(L S F)$ show that runoff and erosion have complex effects on vegetation activity. Greater values of $W$ and $L S F$ will lead to stronger capacity to produce runoff and transport sediment, and thereby increase soil water content and soil deposition, whereas beyond a certain threshold runoff and erosion are so strong that they would destruct vegetation growth. This study provides information needed to successfully restore native vegetation, improve land management, and promote sustainable development in mountainous areas especially for developing regions. However, the impacts of uncertainty and accuracy of land cover classification from remote sensing images on these results should be further studied.

\section{Acknowledgement}

The authors wish to express their gratitude to the National Natural Science Foundation of China (40621061) and the Project of Chinese Academy of Sciences (KZCX2-XB2-02-31) for their financial support. Thanks go to two anonymous reviewers for their kindly improving the manuscript.

Jordan, G., Van Rompaey, A., Szilassi, P., et al. 2005. Historical land use changes and their impact on sediment fluxes in the Balaton basin (Hungary). Agriculture, Ecosystems \& Environment 108: 119-133.

LI Ainong, WANG Ansheng, LIANG Shunlin, et al. 2006. Ecoenvironmental vulnerability evaluation in mountainous region using remote sensing and GIS-a case study in the upper reaches of Minjiang River, China. Ecological Modeling 192: $175-187$.

LI Fanglan, BAO Weikai, and LIU Junhua, 2005. Leaf characteristics and their relationship of Cotinus coggygria in arid river valley located in the upper reaches of Minjiang River with environmental factors depending on its altitude gradients. Acta Botanica Boreali-Occidentalia Sinica 25 (11): 2277-2284. (In Chinese)

LI Fanglan, BAO Weikai, LIU Junhua, et al. 2006. Ecoanatomical characteristics of Sophoral davidii Leaves along an elevation gradient in upper Minjiang River dry valley. Chinese Journal of Applied Ecology 17(1): 5-10. (In Chinese)

Linderman, M. A., LI An, Berarer, S., et al. 2006. Interactive effects of natural and human disturbances on vegetation dynamics across landscapes. Ecological Applications 16(2): $452-463$.

LIU Jiyuan, LIU Mingliang, ZHUANG Dafang, et al. 2003. 
Study on spatial pattern of land-use change in China during 1995-2000. Science in China (Series D) 46(4): 373-384.

LIU Baoyuan, Nearing, M. A. and Risse, L. M. 1994. Slope gradient effects on soil loss for steep slopes. Transactions of the Americal Society of Agricultural Engineers 37(6): 18351840.

LIU Guohua, ZHANG Jieyu, ZHANG Yuxin, et al. 2003. Distribution regulation of aboveground biomass of three main shrub types in the dry valley of Minjiang River. Journal of Mountain Science 21(1): 24-32. (In Chinese)

MA Keming, FU Bojie, LIU Shiliang, et al. 2004. Multiple-scale soil moisture distribution and its implications for ecosystem restoration in an arid river valley, China. Land Degradation and Development 15: 75-85.

Moore, I. D., Grayson, R. B. and Ladson, A. R. 1991. Digital terrain modeling: a review of hydrological, geomorphological and biological applications. Hydrological Processes 5: 3-30.

Moore, I. D., Burch, G. J. and Mackenzie, D. H. 1988. Topographic effects on the distribution of surface soil water and the location of ephemeral gullies. Transactions of the Americal Society of Agricultural Engineers 31: 1098-1107.

Morawitz, D. F., Blewett, T. M., Cohen, A., et al. 2006. Using NDVI to assess vegetative land cover change in central Puget
Sound. Environmental Monitoring and Assessment 114: 85106.

Pinder Ш, J. E., Kroh, G. C., White, J. D., et al. 1997. The relationship between vegetation type and topography in Lassen Volcanic National Park. Plant Ecology 131: 17-29.

Sellers, P. J. 1985. Canopy reflectance, photosynthesis and transpiration. International Journal of Remote Sensing 6: 1335-1372.

Vitousek, P. M. 1994. Beyond global warming: Ecology and global change. Ecology 75: 1861-1876.

Wischmeier, W. H., Smith, D. D. 1978. Predicting rainfall erosion losses: a guide to conservation planning. Agriculture Handbook. Washington DC: US Department of Agriculture, No.537.

XU Xianli, MA Keming, FU Bojie, et al. 2008a. Influence of three plant species with different morphologies on water runoff and soil loss in a dry-warm river valley, SW China. Forest Ecology and Management 256: 656-663.

XU Xianli, MA Keming, FU Bojie, et al. 2008b. Relationships between vegetation and soil and topography in a dry-warm river valley, SW China. Catena 78: 138-145.

ZHANG Rongzu, 1992. The Arid Valleys of the Hengduan Mountains Region. Beijing: Science Press. (In Chinese) 